\title{
MKL1/RBM15 Fusion Gene
}

National Cancer Institute

\section{Source}

National Cancer Institute. MKL1/RBM15 Fusion Gene. NCI Thesaurus. Code C99703.

A fusion gene that results from a chromosomal translocation $\mathrm{t}(1 ; 22)(\mathrm{p} 13 ; \mathrm{q} 13)$ which fuses the 5' portion of the MKL1 gene to the 3' portion of the RBM15 gene. This rearrangement is associated with infantile acute megakaryoblastic leukemia. 